Meta

Journal des traducteurs

Translators' Journal

\title{
Mapping the Process of Translation
}

\section{Janet Fraser}

Volume 41, numéro 1, mars 1996

Le(s) processus de traduction / Translation Process(es)

URI : https://id.erudit.org/iderudit/002772ar

DOI : https://doi.org/10.7202/002772ar

Aller au sommaire du numéro

Éditeur(s)

Les Presses de l'Université de Montréal

ISSN

0026-0452 (imprimé)

1492-1421 (numérique)

Découvrir la revue

Citer cet article

Fraser, J. (1996). Mapping the Process of Translation. Meta, 41(1), 84-96. https://doi.org/10.7202/002772ar

\section{Résumé de l'article}

L'auteur cherche à déterminer s'il est préférable que les apprentis traducteurs reçoivent une formation axée sur le produit de la traduction plutôt que sur le processus mental. Elle montre brièvement que la théorie actuelle de la traduction n'est parfois pas en mesure d'aider les étudiants et les professionnels; elle présente ensuite les résultats de deux études faites auprès de traducteurs professionnels en cours de travail et, à partir de l'analyse des processus observés chez les professionnels, elle esquisse quelques principes pour une approche systématique de la formation des traducteurs. 


\title{
MAPPING THE PROCESS OF TRANSLATION
}

JANET FRASER

University of Westminster, London, United Kingdom

\begin{abstract}
Résumé
L'auteur cherche à déterminer s'il est préférable que les apprentis traducteurs reçoivent une formation axée sur le produit de la traduction plutôt que sur le processus mental. Elle montre brièvement que la théorie actuelle de la traduction n'est parfois pas en mesure d'aider les étudiants et les professionnels; elle présente ensuite les résultats de deux études faites auprès de traducteurs professionnels en cours de travail et, à partir de l'analyse des processus observés chez les professionnels, elle esquisse quelques principes pour une approche systématique de la formation des traducteurs.
\end{abstract}

\begin{abstract}
The aim of this article is to consider whether the training of student translators should be product-driven or process-driven. The author briefly comments on why current translation theory sometimes seems unhelpful to trainee and practising translators. Then she presents the findings of two studies of professional translators at work, and finally, from an analysis of the processes professionals engage in, she draws up some principles for a systematic approach to translator training.
\end{abstract}

\section{INTRODUCTION}

If you wish to make a journey by car, there are two possible ways of deciding on a route. One is to ask a motoring organisation for a route for the proposed journey which will set out the quickest and most direct way of reaching your destination in the form of a set of detailed, stage-by-stage, instructions. That way is destination-oriented. The alternative is to pore over maps and weigh up the alternatives in terms of whether you prefer driving on motorways or along scenic routes; you may also wish to take account of the reason for the journey - business or pleasure - and of such other factors as who else will be travelling with you, the extent to which one route may be affected by weather conditions, and so on. That way is journey-oriented.

The aim of this article is to consider whether student translators are best served by a destination-oriented approach to learning to translate or by a journey-oriented one - in other words, should their training be product-driven or process-driven, governed by theory or governed by appropriate practice?

In attempting to answer the question, I shall briefly comment on why current translation theory sometimes seems unhelpful, and even irrelevant, to trainee and practising translators, despite a shift in recent years away from a purely theoretical approach and towards integration of practice. I shall then present the findings of two studies of professional translators at work. From an analysis of the processes professionals engage in, I shall, finally, attempt to draw up some principles for a systematic approach to translator training which provides a set of co-ordinates for determining an appropriate approach to a translation task rather than a detailed set of instructions or, indeed, a blanket prescription. 


\section{A SURVEY OF THE LANDSCAPE}

Lörscher (1992: 426) has usefully summarised why recent approaches to translation theory have served both trainee and practising translators poorly, a summary which is worth reproducing at some length:

Until very recently, translation theory has been primarily concerned with two phenomena: with translation as a product and with translation competence. [...] Models [of the former] have been prescriptive rather than descriptive and of very limited use to the practical translator. [...] Models [of the latter] were theoretical and speculative rather than empirical. As a consequence of translation theory being product- and competence-oriented, hardly any attention has been given to the process by which a translation is produced, and to translators' actual performance. This narrowing [has] only recently been realised to be a deficit. As a result, a new process-oriented, performance-analytical discipline within translation studies has developed.

Product-based approaches to translation theory focus largely on description and comparison of linguistic structures, especially semantic structures, often at the expense of other text-features such as cultural content. Gentzler (1993: 65) claims that much of German Übersetzungswissenschaft is "designed to identify and describe finished products," and indeed, Catford (1965) is typical in focusing in his discussion of "untranslatability' on linguistic versus cultural untranslatability. $\mathrm{He}$ comments that cultural untranslatability is usually "less absolute" than linguistic untranslatability (99), a term he does not define, however (101-103):

It may be questioned whether the distinction is ultimately necessary [...] to talk of cultural untranslatability may be just another way of talking about collocational untranslatability the impossibility of finding an equivalent collocation in the TL [target language]. And this would be a type of linguistic untranslatability. cal, level:

Newmark (1988: 193), too, focuses on linguistic structures at an even lower, lexi-

The SL [source language] text consists of words, that is all that is there on the page. Finally all you have is words to translate and you have to account for each of them somewhere in your TL text,

although he does concede that:

you translate words that are [...] conditioned by a certain linguistic, referential, cultural and personal context.

Henry (1984: 157) argues, however, that:

Resorting to linguistic translation can deviate from the translator's objective which is highly pragmatic: getting the message across...

while $\mathrm{Hu}$ (1993: 457) makes it clear that:

Since content and form are an inseparable entity, they cannot - and should not - be treated in isolation. [...] The SL content-form entity as a whole should be approximated, not merely the SL form or the SL content.

To focus exclusively on the form - lexical equivalents or linguistic structures - is to ignore the need to translate the content, which is not merely referential but also cultural. Moreover, such a theory does not answer the trainee translator's twin concerns: 'How far away from the original can I go?' and 'I know what it means, but I don't know how to put it in the target language.' 
Nida has attempted, in his extensive work on Bible translation, to resolve this difficulty, replacing a linguistic shift between SL and TL with a new concept of the 'receptor language' in which 'dynamic equivalence' (Nida 1964: 159) should be achieved by the translator:

The receptors of the message in the receptor language [should] respond to it in substantially the same manner as the receptors in the source language; (Nida and Taber 1974: 24)

The relative adequacy of different translations of the same text can only be determined in terms of the extent to which each translation successfully fulfils the purpose for which it was intended. (Nida 1976: 64)

This approach makes some move towards acknowledging the cultural content of the text for translation and recognising that different cultures may respond differently to different content and that, hence, the translation process needs to take account of readers' responses to text. Nida argues that what should determine translation strategy is not a concern with form but the need for the reader in the receptor language and culture to understand and react to the text in the same way as the reader in the source language and culture.

The approach is, however, arguably of limited application to translation more generally for two reasons. First, it requires that texts produce some kind of emotional response on the part of the reader, and while this is true of Bible translation and of literature, perhaps, it is more limited relevance to most other text-types. Bell (1985: 284) argues that:

Translation cannot be and is not being limited to the literary and theological. Technological advance $[\ldots]$ demands more and more translation of a greater range of texts.

There must also, therefore, be a theory which accounts for a wider range of texts for differing purposes and differing audiences.

Second, Nida's position starts from a proselytising stance and deals with an endproduct which is the religious conversion of readers or receptors. The dominant components in such a theory are the concern to influence receptor behaviour as a result of the translation and the risks inherent in conveying a new, potentially alien set of ideas and beliefs to a community that is completely unfamiliar with and potentially hostile to them.

Nida asserts (1969: 489) that:

Our [Bible translators'] choice of models [...] must be dictated essentially by their practical usefulness and their explanatory power (emphasis added).

As Gentzler (1993: 58) argues, "Nida does not trust readers to decode texts for themselves." Since both 'usefulness' and 'explanatory power' could be seen as being at the far end of a reader response spectrum, such an approach has only limited value in terms of more general applicability to translation of a variety of material, although - as I shall show in my account of my own empirical findings - the notion of the reader's needs is nevertheless a crucial one in determining translation strategy.

Translation studies then focused more on what Lörscher calls the competencebased approach to translation theory, in such work as Bassnett (1980), Bassnett and Lefevere (1980), Even-Zohar and Toury (Eds) (1981) and Venuti (1992). While this approach has focused less on the end product and more on the means by which it may be achieved, it still has three main disadvantages for trainee and practising translators.

First, its roots are in the translation of literary works and other material with a high level of cultural and emotive content. The same reservations apply as to Nida - that this represents one end of a much broader spectrum of both text-type and reader-response requirements. 
Second, against the background of a proliferation of debate around literary theory, much of this approach is extremely abstract, philosophical and speculative: for example, Venuti (1992) takes a sociological and ideological approach to translation of literary and political material, focusing on notions of 'unequal cultural exchange' and on how such socio-political factors as post-colonialism affect what he describes in very loaded vocabulary as "a labour of acculturation which domesticates the foreign text" (5). Only a small minority of translators deal exclusively with such material, and if theory is to help all translators, it needs to address a wider range of issues.

Finally, Lörscher (1992: 426) comments on another disadvantage of competencebased models: they concentrate on "idealisations rather than on actually occurring data."

Both models - the product-oriented as well as the competence-based one - have, moreover, attracted criticism, especially - though not exculsively - from those training future generations of translators, both because they do not provide an adequate framework for solving problems of the kind encountered by learners and because they do not differentiate adequately between different types of translation text and translation activity.

Yet, as De Beaugrande, cited in Bell (1991), argues:

It is inappropriate to expect that a theoretical model of translation should solve all the problems a translator encounters. Instead, it should formulate a set of strategies for approaching problems and for co-ordinating the different aspects entailed.

\section{CHARTING NEW TERRITORY}

Hence the shift, over the last few years, to an approach based more on the processes involved in translation than on the product which results from it. Scholars had long argued the need to understand how translators worked. Firth (1957: 27) claimed that:

One of the most important assignments for linguists in the future is the formulation of satisfactory theories of the nature of the translation bridges between languages [...] translators know they cross over but do not know by what sort of bridge.

Steiner (1975: 273) agreed:

We know next to nothing of the generic process which has gone into the translator's practice, of the prescriptive or purely empirical principles, devices, routines which have controlled his choice of this equivalent rather than that.

Yet by 1987, Gerloff was still arguing (136) that:

our ability to understand translation processing per se remains negligible (emphasis in original).

As both Bell (1991) and Lörscher (1992) point out, the last few years have seen a number of 'think-aloud protocol' studies of the translation process: these include Gerloff (1986, 1987 and 1988); Jääskeläinen (1987 and 1989); Lörscher (1991 and 1992); Krings (1986 and 1987); Séguinot (1989, 1990 and 1991, inter alia); and Tirkkonen-Condit (1989). All these studies looked at 'actually occurring data' to try to map the translation process, yet the majority have focused not on professional translators but on students and language-learners. If the aim of translator training is to prepare trainees for efficient professional practice, then the more logical focus for study of the process seems to be the professionals themselves.

It is against this background that I have, over the past four years, carried out two empirical studies of professional translators. The first was of a group of 12 community translators, working in the United Kingdom and translating from English into Arabic, Bengali, Gujarati, Hindi, Panjabi, Spanish and Urdu, while the second was of 21 free- 
lance commercial translators, also working in the United Kingdom and translating from French into English. The community translators translated a local authority leaflet on categories of exemption from the then existing 'community charge' or 'poll tax,' a tax on individuals introduced in 1990 by the UK's Conservative government, set locally and since replaced by another local tax; the commercial translators translated an article from the education supplement of a major French daily newspaper on changes in some university courses in France. The findings reported below are drawn from both studies.1 For brevity, I shall refer to the sample for the first study as 'the community translators' and that for the second study as 'the commercial translators.'

The method chosen to study the process was introspection, a method which has been well-documented (Ericsson and Simon 1980 and 1985; Færch and Kasper 1987). Krings (1986: 265) describes it as providing "the most direct means of access to the translation process." With one exception, the community translators produced their protocols by 'immediate retrospection' (Mann 1982) - that is, the protocol immediately followed completion of a chunk of the translation task - while the 21 commercial translators all gave concurrent 'think-aloud' accounts of their performance.

\section{SIGNPOSTS TO THE TRANSLATION PROCESS}

This section of the paper will reproduce findings from both studies under a number of headings and the final section will draw some provisional conclusions for an approach to translator training.

\section{Influence of the translation brief and TL readership}

The commercial translators were given a brief for their translation task, which was to translate the article for publication in the international news section of The Times Higher Education Supplement, a weekly newspaper reporting on developments in higher education in the United Kingdom and abroad. The community translators were not given any such brief although, as I shall demonstrate below, they did often assume one in the way they tackled certain translation difficulties.

The register of both the SL and the TL was a crucial factor in assessing and carrying out the translation task for both groups of translators. The community translators made such comments on the local authority leaflet as:

'This text is not really for public consumption, it's for well clued-up people only',

or:

'This is an absolute nightmare [...] [the translation is going to have] to be addressed to a general public, from professionals to less professional, let's put it that way'.

There was agreement among the 12 community translators that to fulfil its purpose - which they perceived as giving information on the basis of which minority language communities would better be able to claim their rights - the translation needed to move beyond simple communication of content and to meet the needs of the TL community for extra information or context. There was, however, disagreement over the extent to which this needed to be done, with comments ranging from:

'There is no need to go too much further unnecessarily, just to give more information with the intention to educate your community because the purpose of the pamphlet is just to inform',

and:

'There's always a danger of over-explanation', 
to:

'If people are to participate, they need to know the system',

and

'From time to time, I've looked at the goal people need to take and wherever possible, I have amplified it or tilted it towards the message for the benefit of the community' (emphasis added).

Between these two ends of the spectrum of reader-response came a more flexible approach to the (perceived) brief:

'What sort of words will penetrate to the readers?';

'I want to provide enough material for them to start to wonder [...] if that's what I can achieve here, that will be more than enough' (emphases added).

I shall tackle the difference of approach within the sample below, in the section on the translator's role.

The commercial translators had an explicit brief which in many cases influenced their translation strategies. They commented not only on the constraints of journalistic style ('I'll try and make it read as a newspaper article would;' 'I understand that first sentence, but how would I write it journalistically?' (emphasis added)) and on specific differences between French and English journalistic register ('We've got to think of how headlines are dealt with here [...] I need a snappier title') but also the more general needs of the TL readership as set out in the brief. These translators made specific judgements of, and comments on, the level of familiarity with French culture and the French education system they were assuming of their readers, such as:

'If you're preparing it for an English-speaking audience, you'll have to make it clear what the system is in France';

'I don't think we can assume that the English reader's going to be completely familiar with the French system. My policy is to be as clear as possible';

'It's really a question of whether you feel that a little bit more would have to be added to make the meaning clear'.

These translators felt that a key part of their role was to be aware of the readers' limitations and to amplify where their judgement was that lack of familiarity was obstructing meaning and understanding; 'there should be as little interference as possible from explanations,' commented one translator in this group.

The translators' views on this question were closely linked with their views on the question of dealing with cultural concepts and I shall explore these before drawing the two headings together into some more general conclusions.

\section{Dealing with cultural concepts}

Where an SL text relating to the social institutions of a particular country has to be rendered into another language, there are several ways of dealing with the cultural concepts which arise. One is to translate the word(s) lexically; an equivalent can be located in the culture of the TL; the concept can be explained and amplified in the TL; and, sometimes in conjunction with the last two options, the SL term itself can be 'borrowed' or 'imported' into the TL.

Lexical translation raises the problem of collocational (non-) overlap, since words and terms which collocate in one cultural system do not necessarily do so in another. The community translators made very little use of lexical translation, and where they did, they often gave a number of alternatives such as the Spanish terms el subsidio infantil, el subsidio familiar and el subsidio por niño for child benefit. 
Locating an equivalent is, however, also problematic since systems do not necessarily overlap to the extent that equivalents are always wholly adequate. Another reason for being wary of equivalents is that language use may vary between communities using the same language. There are substantial differences between British and American English, for example, or the Spanish spoken in Spain and in Latin American countries (which also differ between themselves). One of the commercial translators, discussing educational terminology, queried 'Are we going to use US or British terminology?', but the commercial translators as a group were reluctant to find equivalents:

'I wouldn't say the French HM Inspectorate [for l'inspection générale de l'administration], even if it were the equivalent' (emphasis in original);

'That [unités de valeur] isn't in line with anything that exists in English - I'll have to try and use something that's got meaning to it in English but doesn't completely distort the French'.

The community translators were also sparing in their use of such equivalents, which they restricted to elements which did seem to be common to a number of countries' systems, such as the concept of being on remand.

By far the most common solution adopted by translators from both groups was to amplify or explain the term in the TL. Among the community translators, the Gujarati translator commented that he would distinguish between differing groups in his target readership when translating community charge/poll tax:

'If people are coming from India, they'd take it as some sort of donation levied by the head of the village, while Gujaratis coming from East Africa had poll tax, so I could translate that for them but amplify it for the others".

Others commented on the need to comment where systems differed:

'I've translated nursing home as "a centre providing medical care" because in Spain you'd go either to a hospital or to an asilo [old people's home]';

'[remand] is a more formalised way of keeping someone until their court hearing [than operates in Mexico, this translator's TL culture]'.

The commercial translators made similar comments, arguing that terms relating to higher education in France, such as les premiers cycles and étudiants de maîtrise ou de troisième cycle, needed to be explained, respectively, as 'first and second years of undergraduate study' and 'postgraduate students.' One commented that giving such explanation was not only 'a very obvious example of helping someone in an area they can't possibly know about' but also '[gave him] as much pleasure in life as almost anything.' Interestingly, though, the first of the two explanations cited is an expansion while the second is a telescoping. This reflects the differences between the French and British systems in the terms used to refer to stages in higher education. In other words, the approach taken to explanation was not always to expand but rather in each case to seek maximum tie-in with what the readers already knew or were familiar with and to expand only where necessary.

Borrowing SL terminology, finally, was perhaps the issue on which the two groups differed most. Mossop's comments (1989: 14) are of interest here:

Readers tend to assign greatest value to statements that appear to originate within their own culture, but the whole point of a translation could be to make readers aware of its outside origin.

The commercial translators were sparing in their retention of SL terminology, doing so in most cases only where their perception of the TL readership was one of an educated 
readership which would be familiar with SL terms and which could find extra interest in reading them (sometimes in parallel with English explanations):

'If I think there may be anyone who knows French, I put the French term after the English translation';

'I have to decide whether I put députés as a French word because that is what their title is in French' (emphasis in original).

There was, however, also a concern that foreign terms should not be made to sound too rooted in British culture:

'It's important not to give a title that sounds too English as we don't have this post [ministre de l'enseignement supérieur et de la recherche]';

'Should I keep the words premiers cycles rather than make it sound like something English?';

'I think "cycle" would be okay [...] here, we're describing the French education system" (emphasis in original).

The community translators, on the other hand, made quite extensive use of borrowed SL terminology. One commented, for example, that:

'People are more likely to have come across the English terms than anything else; the equivalents, certainly in Mexico, would be meaningless to them',

while another argued:

'if you use merely translation, people may confuse one thing for another [...] so using the English expression puts you on the same side'.

One key reason for this was that since the readers of the $\mathrm{TL}$ version were living in Britain, they already had a great deal of knowledge about the terms used in connection, for example, with social security benefits they might be drawing:

'They all have benefit books, so they'll know the terms';

'I've left the English term poll tax because they'll see it all over the place";

'Due to the publicity around the new tax, I'm assuming people are familiar with it [hence no explanation, just the English term and a transliteration, in this case into Urdu]'.

The differing practice between the two groups on this issue, and their comments on the other issues, are a function largely of their relationship with the TL community and readers and their perception of the role of both the translation activity and themselves as translators.

\section{The translator's role}

I have depicted some fairly wide divergence of practice in the strategies employed not only by the two groups of translators but also within the group of community translators. Does this mean, then, that the findings of these studies are unreliable and tell us nothing about the way professionals translate? I believe that the divergence is motivated not by a lack of common professional standards but, on the contrary, by a very clear perception both of the identity and needs of the target readership in specific cases and of the translator's own role and involvement in the process of translation.

As I have commented above, the commercial translators had a clear perception of their role as one of conveying meaning and providing only as much additional information as was needed to place the text and the changes it describes in context for the (clearly-identified) TL readers. This was limited to adding information about the workings of the French education or legal systems, for example, or clarifying the role of certain organisations or the identity of persons referred to. Phrases such as 'making it clear...' or 'you 
can't assume that the readers are going to be familiar with...' predominated in the protocols these translators produced.

This was in line with an explicit brief which the commercial translators interpreted as an instruction to target an educated readership with a special interest in the latest developments in education but not (necessarily) knowledge of the French system in particular. One quote neatly summed up the approach:

'It's a question of whether you feel that a little bit more would have to be added to make the meaning clear' (emphasis added).

The community translators, by contrast, differed markedly from one another in their perception of the role of the translator and the extent to which they adopted strategies such as amplification or giving additional information. As I have already indicated, they expressed a range of views in their protocols, from the translator who explicitly ruled out giving more information 'just to educate your community' and argued that 'the shorter and clearer [a leaflet] is, the better' to the translator who described the translation of material into community languages as 'the first step towards making the jump to the host culture' and another, cited above, who referred to 'tilting' the message 'for the benefit of the community.'

Yet these wide-ranging views were not random; they reflected not only the translators' own professional involvement but also their involvement with and perception of the needs of the TL readership. The translator cited above who resisted giving extra information and sought to keep translations short and uncluttered worked for a majority of his time as a court interpreter, a situation in which the setting imposes immense restrictions on the way in which the linguistic transfer is dealt with. The formulae of legal language have to be respected, so that everyone involved is absolutely clear about what is going on; time constraints may prevent additional context being given; and the purpose for which the interpreter is engaged is a very circumscribed one - to remove the linguistic barriers to justice being done - which requires the interpreter impartially to meet the needs of both sides.

The other two translators cited above, from the other end of the spectrum, were by contrast both involved with their TL communities not only as members but also as community workers, albeit unofficial ones. The translator who referred to "making the jump to the host culture' was, moreover, working with a community of Chilean refugees, that is, a community which had not chosen to come to Britain and of which it might be argued that it would have more difficulties in integrating, coming to terms with a different system and so on. Her underlying aim as a translator was to ease the process and to protect the rights of a suffering community, a radically different agenda from the court interpreter's, although an equally valid one.

Central to both positions, and to those which lay between these extremes, is an assumption that the role of the translator is to meet the TL community where it currently is in terms of its knowledge and understanding of the SL, its familiarity with and integration into the SL culture and its needs if it is to be able to claim its rights and participate fully in the life of the SL culture - in short, the extent to which the TL community needs to be 'empowered.' Nida and Reyburn (1981: 25-26) comment, in a parallel with this type of translation, that:

The Bible translator's task is not primarily work for the church but with the church $[\ldots]$ involved concern [emphasis added].

Nida's own logical conclusions from this are, however, as I have already described, rather too narrow to apply across the board to a wider variety of translation texts. Nida also assumes homogeneity in his receptors in terms of their lack of familiarity with the 
ideas contained in the Bible, whereas the community translators in this study were aware of the (differing) level of prior knowledge and experience they could assume of their readers. They were also keen to build on existing knowledge of English and concepts within British culture rather than to site everything within the TL culture:

'Those who have settled here are quite aware of the services [available] and already know quite a lot about them';

'I've discovered that many actually illiterate Moroccans do call a social worker a social worker [the English term]';

'We're really translating for people who are living here, and if they're newcomers, they eventually need to know these words and phrases'.

One put it rather dramatically:

'The underlying goal is always for people to learn the language - interpreters postpone people learning to help themselves'.

The two groups could be seen as perhaps expressing the strong and weak forms respectively of the hypothesis that there is no such thing as 'the' right way to translate a text, but lots of 'right' ways, and that the 'rightness' of any one translation will depend, solely or largely, on the nature of the TL readership and the translator's own perception of his/her role. This hypothesis, which I would like to offer as an alternative orientation in translator training, has a number of implications and opens up new avenues for research.

\section{A NEW APPROACH TO TEACHING TRANSLATION?}

I should emphasise that I have not assumed any particular model of translation theory in interpreting the protocols produced by my informants. An initial response to the findings I have presented and the conclusions I am drawing from them may be that no overall alternative theory or model of translation emerges either. Rather, I have sought as I indicated at the beginning of this article — to outline a set of co-ordinates which may help trainee translators on their journey through the translation process to their end destination. Firth (1956: 88) comments:

It is as well to remember that different disciplines have entirely different attitudes towards the use of translations.

It is clear from the findings of my two studies that the translators involved adopted a targetted approach to their translation activity rather than an overall approach.

A key element in this was, as I have already commented at length, the translators' perception of the needs of the target readership and of their own role in relation to that readership. Kingscott (1992: 48) comments:

You need to know what are the readers' expectations and requirements [...] an applicationdriven approach [...] will [result in translation being] perceived as a dynamic, purpose-driven re-creation.

The question of the brief was, however, also crucial. I would disagree with Reiss and Vermeer, cited in Jääskeläinen (1989: 95-96), who argue that:

It would seem that [...] professional translators' decisions concerning the translation assignment [brief] are in the majority of cases automatised and therefore not observable in protocols.

In my two studies, the brief explicitly underpinned many of the comments made even where, as in the case of the community translators, a specific brief had not been 
given. Jääskeläinen (1987) comments that there is too little variety in the translation assignments given in translator training and opines that it might be useful to encourage trainee translators to forget the confines of structure and style by setting translation exercises "with a clearly different function than [sic] that of the source text" (68). This assumes that briefs are commonly being given to trainee translators; I suspect, however, that this is not the case and that the practice of assigning a brief needs to be more widely adopted. Indeed, Krings (1986: 501) comments from his own study of students that:

Eine der wichtigsten Beobachtungen in den Daten war die, daß die Versuchspersonen, obwohl ständig mit Übersetzungsaufgaben konfrontiert, einen völlig ungenügenden Grad übersetzerischen Problembewußtseins aufwiesen [...] [Eine der] wichtigsten Erscheinungsformen [war] mangelnde Reflexion der Funktion der Übersetzung; [one of the most important observations to emerge from the data was that although the students in the sample were regularly confronted with translation tasks, they had a completely inadequate level of awareness of translation issues [...] [one of] the most important manifestations of this [was] giving insufficient weight to the function of the translation] (Janet Fraser's translation).

I believe we have to give our trainee translators an explicit brief for their translation tasks, coupled with extensive discussion of the nature of SL and TL register, the needs of particular readerships and the factors which would guide, for example, the use of lexical or cultural equivalents. How else are our trainee translators to judge the 'appropriateness' of their own translations unless they have a set of assumptions about different readers against which to judge appropriateness in a particular context?

There are, moreover, marked differences between the data emerging from these studies and the findings of similar studies using student translators. The latter focus typically on such things as linguistic structures, individual lexical difficulties or unclear meaning and, hence, on translation strategies as defined by Lörscher (1992: 428): "procedures which the subjects employ in order to solve translation problems." Students of translation are, logically, going to be confronted with "translation problems" of a differing nature from those confronted by more experienced professional translators and will, therefore, be more likely to focus on surface features. Their accounts may therefore tell us something about the problems people have (and articulate) when learning to translate, but they will not give us much information about the successful ways they have found of dealing with those problems; it is the problems themselves which are being attended to and hence made available in short-term memory, not ways of overcoming them.

My studies of professional translators, on the other hand, focused much less on individual difficulties and more on general approaches, such as the assumptions they were making about the TL readership or the specific stylistic differences between SL and TL texts. Not only do such approaches constitute a working set of principles for producing a translation, moreover, they also constitute a framework for resolving any individual difficulties which occur. In other words, the "translation problems" which are articulated by professionals are set in a broader context — of appropriateness to a particular communicative task - and resolved by reference to that same context. What is available in short-term memory in such cases are not isolated linguistic problems but more generalised communicative goals, and it is these goals which produce the answers to the problems which arise.

Gerloff's (1988) parallel study of students, bilinguals and professionals reinforces this contrast:

As people become more proficient in the [source] language and are therefore able successively to step into higher levels of processing [...] a much larger and clearer sense of context is enabled (132); 
It is as if greater automaticity at one level 'frees up' processing capacity which may then be focused on other, more complex levels of analysis (54).

Finally, some comments should perhaps be made on the protocol method itself. It is indeed an excellent tool for providing access to the translation process, but the material to which access is gained varies according to what is in the translators' short-term memory and, indeed, their own confidence with the translation process. Some translators in both groups gave protocols concerned largely with surface features while others commented in some detail on more 'philosophical' issues, including their own personal approaches to translation. The language they used was, moreover, often very personal, even emotional, conveying a high level of emotional commitment to and involvement in the work. However, as an impression (and not one that I can yet quantify), it seemed that this level of engagement also bore some relation to their level of confidence, either in the translation activity as a whole or in the specific task allocated for the purposes of the study. There is, too, no doubt that this method itself does impinge on the way the translator goes about the task, even though most translators cope well with and even benefit from the need to verbalise.

Without a detailed personality profile of each translator accompanying his or her protocol, including reactions to the need to verbalise, it therefore seems over-ambitious to attempt to quantify specific strategies and solutions from such data. What they do illustrate is, however, a working framework for the successful resolution not only of surface difficulties but also of macro-level, task-related problems. I believe that this is where the benefit of such data for understanding the translation process lies: not in prescriptions for individual difficulties but in a functional set of approaches to achieving a particular (communicative) task. Those of us who train translators should, therefore, be integrating these findings into our teaching, to give trainee translators a clearly-perceived destination and confidence in their ability to use various factors to devise the most appropriate route to reach it.

\section{Note}

1. Many of the findings included here from the first study were first published in Applied Linguistics vol. 14 $\mathrm{n}^{\circ} 4$ (Fraser 1993), while those from the second study were first presented to the 7 th annual conference of the Institute of Translation and Interpreting in April 1994.

\section{REFERENCES}

BASSNETT-McGUIRE, S. (1980): Translation Studies, London, Methuen.

BASSNETT, S. and A. LEFEVERE (Eds) (1990): Translation, History and Culture, London, Pinter Publishers.

BELL, R. T. (1991): Translation and Translating: Theory and Practice, London, Longman.

CATFORD, J. C. (1965): A Linguistic Theory of Translation, Oxford, Oxford University Press.

ERICSSON, K. A. and H. A. SIMON (1980): "Verbal Reports as Data", Psychological Review, 87-3, pp. $215-251$.

ERICSSON, K. A. and H. A. SIMON (1985): "Protocol Analysis", T. van Dijk (Ed.), Handbook of Discourse Analysis, Vol. 2, London, Harcourt Brace Jovanovich.

EVEN-ZOHAR, I. and G. TOURY (Eds) (1981): Translation Theory and Intercultural Relations (Poetics Today, 2-4).

FERCH, C. and G. KASPER (Eds) (1987): Introspection in Second- Language Research. Clevedon, Multilingual Matters.

FIRTH, J. R. (1956): "Linguistics and Translation", F. R. Palmer (Ed.), Selected Papers of J. R. Firth 19521959, London, Indiana University Press (published 1968).

FIRTH, J. R. (1957), "A Synopsis of Linguistic Theory 1930-1955", J. R. Firth (Ed.), Studies in Linguistic. A Special Volume of the Philological Society, Oxford, Blackwell (published 1968).

FRASER, J. E. (1993): "Public Accounts: Using Verbal Protocols to Investigate Community Translation", Applied Linguistics, 14-4, pp. 325-343. 
GERLOFF, P. (1986): "Second-language Learners' Reports on the Interpretive Process: Talk-aloud Protocols of Translation", J. House and S. Blum-Kulka (Eds), Interlingual and Intercultural Communication: Discourse and Cognition in Translation and Second Language Acquisition Studies, Tübingen, Narr.

GERLOFF, P. (1987): "Identifying the Unit of Analysis in Translation: Some Uses of Think-aloud Protocol Data", Færch, C. and G. Kasper (Eds), Introspection in Second- Language Research, Clevedon, Multilingual Matters.

GERLOFF, P. (1988): From French to English: a Look at the Translation Process in Students, Bilinguals and Professional Translators, unpublished doctoral dissertation, Harvard University, University Microfilms International.

JÄÄSKELÄINEN, R. H. (1987): What Happens in a Translation Process: a Think-aloud Protocol Study, unpublished pro gradu thesis, Savonlinna School of Translation Studies, University of Joensuu.

JÄÄSKELÄINEN, R. H. (1989): "Translation Assignment in Professional Versus Non-professional Translation: a Think-aloud Protocol Study", C. Séguinot (Ed.), The Translation Process, Toronto, H.G. Publications, School of Translation, York University.

KINGSCOTT, G. (1992): “Editorial", Language International, 4-4, p. 48.

KRINGS, H. P. (1986): Was in den Köpfen von Übersetzern vorgeht: eine Untersuchung zur Struktur des Übersetzungsprozesses an fortgeschrittenen Französischlernern, Tübingen, Narr.

KRINGS, H. P. (1987): "The Use of Introspective Data in Translation", C. Færch and G. Kasper (Eds), Introspection in Second-Language Research, Clevedon, Multilingual Matters.

LÖRSCHER, W. (1991): "Thinking-aloud as a Method for Collecting Data on Translation Processes", S. Tirkkonen-Condit (Ed.), Empirical Research in Translation and Intercultural Studies, Tübingen, Narr.

LÖRSCHER, W. (1992): "Investigating the Translation Process", Meta, 37-3, pp. 426-439.

MANN, S. J. (1982): "Verbal Reports as Data: a Focus on Retrospection", S. Dingwall and S. J. Mann (Eds), Methods and Problems in Doing Applied Linguistic Research, Lancaster, University of Lancaster.

MOSSOP, B. (1989): "Write Idiomatically, and Translate Ideas, Not Words": Three Defects of the Prevailing Doctrine of Translation", C. Séguinot (Ed.), The Translation Process, Toronto, H.G. Publications, School of Translation, York University.

NEWMARK, P. (1988): A Textbook of Translation, London, Prentice Hall.

NIDA, E. A. (1964): Towards a Science of Translating, Leiden, Briil.

NIDA, E. A. and C. R. TABER (1974): The Theory and Practice of Translation, Leiden, Brill.

NIDA, E. A. (1976): "A Framework for the Analysis and Evaluation of Theories of Translation", R. W. Brislin (Ed.), Translation: Applications and Research, New York, Gardner Press.

NIDA, E. A. and W. D. REYBURN (1981): Meaning Across Cultures, Maryknoll (N.Y.), Orbis Books.

SÉGUINOT, C. (Ed.) (1989): The Translation Process, Toronto, H.G. Publications, School of Translation, York University.

SÉGUINOT, C. (1990): "Interpreting Errors in Translation", Meta, 35-1, pp. 68-73.

SÉGUINOT, C. (1991): "A Study of Student Translation Strategies", S. Tirkkonen-Condit (Ed.), Empirical Research in Translation and Intercultural Studies, Tübingen, Narr.

STEINER, G. (1975): After Babel: Aspects of Language and Translation, Oxford, Oxford University Press.

TIRKKONEN-CONDIT, S. (1989): "Professional Versus Non-professional Translation: a Think-aloud Protocol Study", C. Séguinot (Ed.), The Translation Process, Toronto, H.G. Publications, School of Translation, York University.

VENUTI, R. (Ed.) (1992): Rethinking Translation, London, Routledge. 